\title{
Cholinergic imaging in dementia spectrum disorders
}

\author{
Roman Roy $^{1} \cdot$ Flavia Niccolini $^{1} \cdot$ Gennaro Pagano $^{1} \cdot$ Marios Politis $^{1}$
}

Received: 12 October 2015 / Accepted: 18 February 2016/Published online: 16 March 2016

(C) The Author(s) 2016. This article is published with open access at Springerlink.com

\begin{abstract}
The multifaceted nature of the pathology of dementia spectrum disorders has complicated their management and the development of effective treatments. This is despite the fact that they are far from uncommon, with Alzheimer's disease (AD) alone affecting 35 million people worldwide. The cholinergic system has been found to be crucially involved in cognitive function, with cholinergic dysfunction playing a pivotal role in the pathophysiology of dementia. The use of molecular imaging such as SPECT and PET for tagging targets within the cholinergic system has shown promise for elucidating key aspects of underlying pathology in dementia spectrum disorders, including AD or parkinsonian dementias. SPECT and PET studies using selective radioligands for cholinergic markers, such as $\left[{ }^{11} \mathrm{C}\right] \mathrm{MP} 4 \mathrm{~A}$ and $\left[{ }^{11} \mathrm{C}\right] \mathrm{PMP}$ PET for acetylcholinesterase (AChE), $\left[{ }^{123} \mathrm{I}\right] 5 \mathrm{IA}$ SPECT for the $\alpha_{4} \beta_{2}$ nicotinic acetylcholine receptor and $\left[{ }^{123} \mathrm{I}\right] \mathrm{IBVM}$ SPECT for the vesicular acetylcholine transporter, have been developed in an attempt to clarify those aspects of the diseases that remain unclear. This has led to a variety of findings, such as cortical AChE being significantly reduced in Parkinson's disease (PD), PD with dementia (PDD) and AD, as well as correlating with certain aspects of cognitive function such as attention and working memory. Thalamic AChE is significantly reduced in progressive supranuclear palsy (PSP) and multiple system atrophy, whilst it is not affected in PD. Some
\end{abstract}

Marios Politis

marios.politis@kcl.ac.uk

1 Neurodegeneration Imaging Group, Department of Basic \& Clinical Neuroscience, Institute of Psychiatry, Psychology and Neuroscience, King's College London, London, UK of these findings have brought about suggestions for the improvement of clinical practice, such as the use of a thalamic/ cortical AChE ratio to differentiate between PD and PSP, two diseases that could overlap in terms of initial clinical presentation. Here, we review the findings from molecular imaging studies that have investigated the role of the cholinergic system in dementia spectrum disorders.

Keywords Cholinergic system $\cdot$ PET $\cdot$ SPECT $\cdot$ Dementia

\section{Introduction}

The population of the developed world is ageing and this has led to an increasing prevalence of dementia. It has recently been estimated that 47.5 million people worldwide suffer from dementia [1]. Dementia is a challenge to society, both in terms of economic cost and social burden, as most patients require long-term care in their home or nursing home [2]. There is clearly a real incentive to find more effective methods of diagnosing and treating this set of diseases, which are not yet as fully understood as many of their other neurodegenerative diseases.

The cholinergic system plays a key role in functional and structural remodelling of cortical circuits underlying cognitive processing [3]. The three major cholinergic projection systems of the central nervous system include (1) the nucleus basalis of Meynert, which supplies cholinergic projections throughout the cerebral cortex and hippocampus [4], (2) the pedunculopontine nucleus pars compacta, which projects to the forebrain as well as various subcortical structures such as the thalamus [5], and (3) cholinergic neurons intrinsic to the striatum [6]. Post-mortem studies have found that muscarinic acetylcholine receptors ( $\mathrm{mAChR})$ are highly expressed in the caudate nucleus and nucleus accumbens in normal monkey 
and human brain [7-9]. In the somatosensory, primary motor and temporal cortices, $\mathrm{mAChR}$ concentrations are about $60 \%$ of the levels in the caudate whilst the cerebellar cortex expresses the lowest levels [8]. Nicotinic acetylcholine receptors (nAChR) are abundantly expressed in the entorhinal, temporal and primary motor cortices, and the hippocampus and thalamus of post-mortem normal human brain tissue [10-12].

Dysfunction of the ascending cholinergic systems from the basal forebrain and brainstem and the associated loss of cholinergic neurotransmission in the cerebral cortex has been suggested as an underlying substrate of cognitive decline (cholinergic hypothesis of dementia), supporting the use of acetylcholinesterase (AChE) inhibitors in dementia [13]. Many post-mortem studies investigating pathophysiological mechanisms of dementia have focused on alterations in functional components of the cholinergic system, such as AChE, the vesicular acetylcholine transporter (VAChT), nAChR, and $\mathrm{mAChR}[14,15]$. Molecular imaging techniques such as SPECT and PET with selective radioligands for targets within the cholinergic system have led to significant advances in the understanding of the neurobiology and pathophysiology of dementia (Fig. 1).

This review discusses the use of cholinergic radioligands in molecular imaging (Tables 1 and 2), with the aim of improving the understanding, and thereby the diagnosis, monitoring and treatment, of dementia spectrum disorders.

\section{Cholinergic system in Alzheimer's disease}

$\mathrm{AD}$ is the leading cause of dementia in the western world, accounting for more than $60 \%$ of cases $[44,45]$. AD is characterized pathologically by accumulation of amyloid $\beta$ peptide $(A \beta)$ in extracellular plaques, intracellular deposits of tau protein, and neuronal loss [46-48]. Evidence for the involvement of the cholinergic system in the pathogenesis of AD was provided as early as the mid-1970s in post-mortem studies showing loss of choline acetyltransferase (ChAT) and AChE in the cortex, hippocampus and amygdala of AD brain samples $[14,49-50]$. Moreover, reduced ChAT activity has been found to be correlated with increased $\mathrm{A} \beta$ plaque load and with cognitive decline $[50,52]$. Degeneration of the cholinergic system affects not only cortical regions but also the nucleus basalis of Meynert, where cholinergic neurons are severely decreased in post-mortem brain tissue of AD patients, highlighting the role of subcortical cholinergic dysfunction in the pathogenesis of $\mathrm{AD}$ [53].

\section{Presynaptic cholinergic dysfunction in Alzheimer's disease}

PET with $N-\left[{ }^{11} \mathrm{C}\right]$ methyl-piperidin-4-yl propionate ([ $\left.\left.{ }^{11} \mathrm{C}\right] \mathrm{PMP}\right)$, a selective substrate for AChE [54], has shown

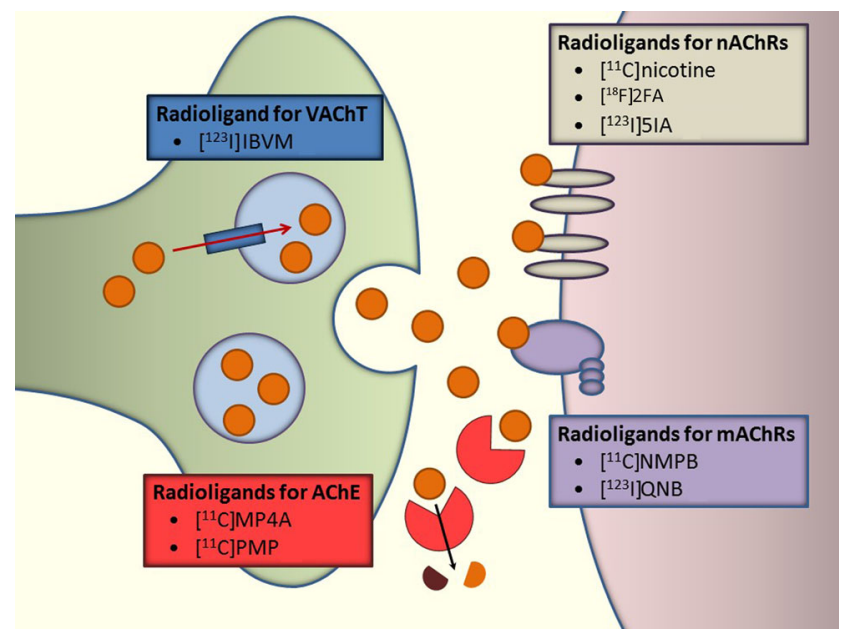

Fig. 1 Schematic illustration of PET and SPECT techniques assessing presynaptic and postsynaptic cholinergic molecular targets with direct relevance to dementia. Acetylcholine $(A C h)$ is degraded to choline and acetate by acetylcholinesterase $(A C h E)$, thereby terminating neurotransmission. The reuptake of choline into the presynaptic neuron occurs via a choline transporter. Choline is recycled within the presynaptic neuron to form $\mathrm{ACh}$ and stored in vesicles through a presynaptic vesicular ACh transporter (VAChT). Two different types of ACh receptors $(A C h R)$ are expressed on the postsynaptic neurons: nicotinic receptors $(n A C h R)$ and muscarinic receptors $(m A C h R)$

a reduction in AChE activity in $\mathrm{AD}$ patients $[17,19,20]$. The degree of AChE activity reduction ranged between $9 \%$ and $33 \%$, depending on the severity of cognitive impairment in the cohort of AD patients examined. Kuhl et al. [17] found decreases in neocortical and hippocampal AChE activity of $25-33 \%$ in patients with moderate-severe $\mathrm{AD}$ and a mean Mini Mental State Examination (MMSE) score of 14. Loss of cortical $\left[{ }^{11} \mathrm{C}\right]$ PMP uptake is associated with reductions in VAChT, as measured by $5-\left[{ }^{123} \mathrm{I}\right]$ iodo-benzovesamicol $\left(\left[{ }^{123} \mathrm{I}\right] \mathrm{IBVM}\right) \mathrm{SPECT}$, but does not correlate with decreases in 2-[ $\left[{ }^{18} \mathrm{~F}\right]$-fluoro-2-deoxy-D-glucose $\left(\left[{ }^{18} \mathrm{~F}\right] \mathrm{FDG}\right) \mathrm{PET}$, which is focally reduced in the posterior cingulate gyrus and parietal cortex [17]. The disagreement in cholinergic and metabolic imaging patterns of degeneration suggests a different mechanism underlying cholinergic and metabolic decline in $\mathrm{AD}$ pathophysiology. Patients with early AD (mean MMSE score 22) showed more modest reductions in cortical AChE activity $(9-11 \%)$ with greater decreases in the lateral temporal cortex $(15 \%)[19,20]$. Overall, in vivo AChE losses tend to be less pronounced than those seen in post-mortem studies, in which $55 \%$ reductions in cholinergic markers have been observed [55].

The modest degree of cholinergic denervation despite the severity of cognitive decline raises questions about the specific role of the cholinergic system in episodic memory processes. In this regard, Bohnen et al. [20] found that decreases in cortical AChE activity were negatively correlated with performance in the WAIS-III digit span test, whereas they were not 
Table 1 Cholinergic PET and SPECT studies using presynaptic cholinergic markers in dementia spectrum disorders

\begin{tabular}{|c|c|c|c|c|c|}
\hline Radiotracer & Target & Reference & $\begin{array}{l}\text { Imaging } \\
\text { technique }\end{array}$ & Subjects & Main findings \\
\hline$\left[{ }^{123} \mathrm{I}\right] \mathrm{IBVM}$ & VAChT & {$[16]$} & SPECT & $22 \mathrm{AD}, 9 \mathrm{PD}, 6 \mathrm{PDD}, 36 \mathrm{HC}$ & $\begin{array}{l}\text { Significant reduction in VAChT levels in entire cortex in } \\
\text { PDD; only reduced in parietal and occipital cortex in PD. } \\
\text { In mildly demented AD patients with age of onset }<65 \\
\text { years, severe reduction in cortical and hippocampal binding. } \\
\text { In AD patients with age of onset }>65 \text { years, VAChT } \\
\text { reductions only in temporal cortex and hippocampus. }\end{array}$ \\
\hline$\left[{ }^{11} \mathrm{C}\right] \mathrm{PMP}$ & $\mathrm{AChE}$ & {$[17]$} & PET & $14 \mathrm{AD}, 26 \mathrm{HC}$ & $\begin{array}{l}\text { Significant reduction in cortical } \mathrm{AChE} \text { activity in } \mathrm{AD} \text { patients. } \\
\text { No significant changes in } \mathrm{AChE} \text { activity in caudate, putamen, } \\
\text { thalamus, pons or cerebellum. }\end{array}$ \\
\hline$\left[{ }^{11} \mathrm{C}\right] \mathrm{MP} 4 \mathrm{~A}$ & $\mathrm{AChE}$ & {$[18]$} & PET & 16 PD, 12 PSP, $13 \mathrm{HC}$ & $\begin{array}{l}\text { Significant reduction in cortical AChE activity in PD }(-17 \%) \text {; } \\
\text { no significant changes in thalamic }\left[{ }^{11} \mathrm{C}\right] \mathrm{MP} 4 \mathrm{~A} \text { uptake in PD. } \\
\text { Significant reduction in thalamic AChE activity in PSP } \\
(-38 \%) \text { but no significant change in cortical binding. } \\
\text { Possible use of thalamic to cortical }\left[{ }^{11} \mathrm{C}\right] \mathrm{MP} 4 \mathrm{~A} \text { binding } \\
\text { ratio for the differential diagnosis of PD and PSP. }\end{array}$ \\
\hline$\left[{ }^{11} \mathrm{C}\right] \mathrm{PMP}$ & $\mathrm{AChE}$ & [19] & PET & $12 \mathrm{AD}, 11 \mathrm{PD}, 14 \mathrm{PDD}, 10 \mathrm{HC}$ & $\begin{array}{l}\text { Highest reduction in cortical AChE activity in PDD }(-20 \%) \text {, } \\
\text { then } \mathrm{PD}(-12.9 \%) \text {, and least in } \mathrm{AD}(-9.1 \%) \text {. Selective } \\
\text { involvement of lateral temporal cortex in } \mathrm{AD}(-15 \%)\end{array}$ \\
\hline$\left[{ }^{11} \mathrm{C}\right] \mathrm{PMP}$ & $\mathrm{AChE}$ & {$[20]$} & PET & $15 \mathrm{AD}, 12 \mathrm{HC}$ & $\begin{array}{l}\text { Significant reduction in cortical AChE activity in AD patients. } \\
\text { Positive correlation between cortical AChE activity and } \\
\text { attention and working memory; no correlation with short-term } \\
\text { or long-term memory. }\end{array}$ \\
\hline$\left[{ }^{11} \mathrm{C}\right] \mathrm{MP} 4 \mathrm{~A}$ & $\mathrm{AChE}$ & {$[21]$} & PET & 17 PD, 10 PDD, $31 \mathrm{HC}$ & $\begin{array}{l}\text { Larger reduction in cortical AChE in PDD }(-29.7 \%) \text { than in } \\
\text { PD }(-10.7 \%) \text {. Close relationship between striatal } \\
{\left[{ }^{18} \mathrm{~F}\right] \text { FDOPA binding and }\left[{ }^{11} \mathrm{C}\right] \mathrm{MP} 4 \mathrm{~A} \text { binding in frontal and }} \\
\text { temporoparietal cortex in PDD. }\end{array}$ \\
\hline$\left[{ }^{11} \mathrm{C}\right] \mathrm{MP} 4 \mathrm{~A}$ & $\mathrm{AChE}$ & {$[22]$} & PET & 11 AD ApoE4+, 8 AD ApoE4- & $\begin{array}{l}\text { Larger reduction in } \mathrm{AChE} \text { activity in ApoE4- than ApoE4+ } \\
\text { patients. }\end{array}$ \\
\hline$\left[{ }^{11} \mathrm{C}\right] \mathrm{PMP}$ & $\mathrm{AChE}$ & {$[23]$} & PET & 13 PD, 11 PDD, $14 \mathrm{HC}$ & $\begin{array}{l}\text { Significant reduction in cortical AChE activity in PDD (-20.9\%) } \\
\text { and PD }(-12.7 \%) \text {. Significant correlation between cortical } \\
\text { AChE and WAIS-III Digit Span test, Trail Making test and } \\
\text { Stroop Color Word test scores in PDD. No significant } \\
\text { correlation between motor symptom severity and cortical } \\
\text { binding. }\end{array}$ \\
\hline$\left[{ }^{11} \mathrm{C}\right] \mathrm{MP} 4 \mathrm{~A}$ & $\mathrm{AChE}$ & {$[24]$} & PET & 18 PD, 10 PDD, 11 DLB, $26 \mathrm{HC}$ & $\begin{array}{l}\text { Significant reduction in cortical AChE activity in PDD and } \\
\text { DLB ( }-27 \%) \text {; no significant difference between PDD and } \\
\text { DLB groups. Significant reduction in cortical binding in PD, } \\
\text { especially in medial occipital cortex ( }-12 \%) \text {; significant } \\
\text { difference between PDD and DLB, and PD groups. }\end{array}$ \\
\hline$\left[{ }^{11} \mathrm{C}\right] \mathrm{PMP}$ & $\mathrm{AChE}$ & {$[25]$} & PET & 12 PD, 13 MSA, 4 PSP, 22 HC & $\begin{array}{l}\text { Significant reduction in AChE activity in most cortical regions } \\
\text { in PD }(-15.3 \%) \text { and MSA ( }(-14.6 \%) \text {; no significant } \\
\text { differences between PD and MSA groups. No significant } \\
\text { changes in cortical binding in PSP. Preferential denervation of } \\
\text { subcortical structures (striatum, cerebellum, thalamus, } \\
\text { midbrain and pons) in MSA and PSP. Significant reduction in } \\
\text { striatal, cerebellar, thalamic binding in PD, but significantly } \\
\text { smaller reduction than in MSA and PSP. }\end{array}$ \\
\hline$\left[{ }^{11} \mathrm{C}\right] \mathrm{MP} 4 \mathrm{~A}$ & $\mathrm{AChE}$ & {$[26]$} & PET & 9 PD, 8 PDD, 6 DLB, $3 \mathrm{HC}$ & $\begin{array}{l}\text { Severe reduction in neocortical AChE activity in PDD and } \\
\text { DLB, with the reduction increasing from frontal (least) to } \\
\text { occipital cortex (most) in both groups. No significant } \\
\text { difference between PDD and DLB groups. Mild cortical } \\
\text { AChE deficit in PD. }\end{array}$ \\
\hline$\left[{ }^{11} \mathrm{C}\right] \mathrm{MP} 4 \mathrm{~A}$ & $\mathrm{AChE}$ & {$[27]$} & PET & 7 CBD, 12 PSP, 8 FTD, 16 HC & $\begin{array}{l}\text { Voxel-based analysis showed significant decreases in AChE } \\
\text { activity in CBD (paracentral region, frontal, parietal and } \\
\text { occipital cortices) and PSP (paracentral region and thalamus). } \\
\text { No significant differences in }\left[{ }^{11} \mathrm{C}\right] \mathrm{MP} 4 \mathrm{~A} \text { binding in FTD. } \\
\text { Volume of interest analysis showed mean cortical AChE } \\
\text { activity reduced by } 17.5 \% \text { in CBD, } 9.4 \% \text { in PSP and } 4.4 \%\end{array}$ \\
\hline
\end{tabular}


Table 1 (continued)

$\begin{array}{lll}\text { Radiotracer Target Reference Imaging Subjects } & \begin{array}{l}\text { Imain findings } \\ \text { technique }\end{array}\end{array}$

\begin{tabular}{|c|c|c|c|c|c|}
\hline & & & & & $\begin{array}{l}\text { in FTD; thalamic AChE activity reduced by } 24.0 \% \text { in PSP but } \\
\text { not in CBD and FTD. }\end{array}$ \\
\hline$\left[{ }^{11} \mathrm{C}\right] \mathrm{PMP}$ & $\mathrm{AChE}$ & [28] & PET & $\begin{array}{l}13 \mathrm{AD}, 11 \mathrm{PD}, 6 \mathrm{PDD}, 6 \mathrm{DLB} \text {, } \\
14 \mathrm{HC}\end{array}$ & $\begin{array}{l}\text { Largest reduction in thalamic AChE activity in PDD }(-19.8 \%) \text {, } \\
\text { then in DLB }(-17.4 \%) \text {, least in PD }(-12.8 \%) . \text { Spared } \\
\text { thalamic AChE activity in AD. }\end{array}$ \\
\hline$\left[{ }^{123} \mathrm{I}\right] \mathrm{IBVM}$ & VAChT & [29] & SPECT & 10 PSP, $12 \mathrm{HC}$ & $\begin{array}{l}\text { Significant reduction in anterior cingulate cortical, } \\
\text { innominatocortical, thalamic and pontothalamic VAChT } \\
\text { levels Thalamic and pedunculopontine binding inversely } \\
\text { correlated with disease duration. }\end{array}$ \\
\hline
\end{tabular}

$A C h E$ acetylcholinesterase, $A D$ Alzheimer's disease, $C B D$ corticobasal degeneration, $D L B$ dementia with Lewy bodies, FTD frontotemporal dementia, $H C$ healthy control, $M S A$ multiple system atrophy, $P D$ Parkinson's disease, $P D D$ Parkinson's disease dementia, $P S P$ progressive supranuclear palsy, $V A C h T$ vesicular acetylcholine transporter

associated with California Verbal Learning Test (CVLT) scores. These results suggest that cholinergic dysfunction is linked to attention and working memory rather than episodic memory. Although cortical cholinergic denervation from the nucleus basalis of Meynert is a feature of $\mathrm{AD}$, the pontine cholinergic projection system to the thalamus has been found to be spared in the disease [28].

PET with $N-\left[{ }^{11} \mathrm{C}\right]$ methyl-4-piperidyl acetate $\left(\left[{ }^{11} \mathrm{C}\right] \mathrm{MP} 4 \mathrm{~A}\right)$, another selective $\mathrm{AChE}$ radioligand, has shown that $\mathrm{AD}$ patients with apolipoprotein $\mathrm{E}$ allele $\varepsilon 4$ (ApoE4) have significantly less pronounced reductions in cortical $\mathrm{AChE}$ activity than those negative for the ApoE4 allele [22]. This suggests that the ApoE4 allele has a protective role against the widespread loss of AChE activity in $\mathrm{AD}$, although the underlying mechanism remains unknown. $\left[{ }^{11} \mathrm{C}\right] \mathrm{MP} 4 \mathrm{~A}$ has shown higher specificity for AChE relative to butyryl cholinesterase [56, 57], but it has a higher hydrolysis rate and thus radioligand uptake in regions of high $\mathrm{AChE}$ activity such as basal ganglia is strongly dependent on the rate of transport into the brain [54]. In contrast, $\left[{ }^{11} \mathrm{C}\right] \mathrm{PMP}$ exhibits a rate of hydrolysis three to four times slower than that of $\left[{ }^{11} \mathrm{C}\right] \mathrm{MP} 4 \mathrm{~A}$, allowing more precise estimates of the $\mathrm{AChE}$ activity in regions of moderate to high AChE concentration [58].

SPECT with $\left[{ }^{123} \mathrm{I}\right] \mathrm{IBVM}$, a selective ligand for presynaptic VAChT, has been used to assess presynaptic cholinergic terminal density [59]. Interestingly, in mildly demented AD patients, the $\left[{ }^{123} \mathrm{I}\right] \mathrm{IBVM}$ binding pattern differs according to age at onset [16]. In patients with early-onset AD (age at onset $<65$ years) loss of cholinergic terminals were observed in the neocortex and hippocampus, whereas in patients with lateonset $\mathrm{AD}$ significant VAChT reductions were limited to the temporal cortex and hippocampus. These findings are consistent with those of post-mortem studies, which have demonstrated more widespread cholinergic degeneration in earlyonset $\mathrm{AD}[60]$. A new PET radioligand with good sensitivity and specificity for VAChT, (-) $5-{ }^{18} \mathrm{~F}$ fluoroethoxybenzovesamicol $\left(\left[{ }^{18} \mathrm{~F}\right] \mathrm{FEOBV}\right)$, has recently been developed and tested in humans [61]. Both reference tissue modelling and late static scanning approaches correlated well with the full kinetic modelling with arterial sampling and plasma metabolite analysis [61]. In comparison with $\left[{ }^{123}\right.$ I]IBVM SPECT, $\left[{ }^{18} \mathrm{~F}\right]$ FEOBV PET showed low binding in the lateral cerebellar cortex and high binding in the mesopontine junction and medulla, providing a robust index of VAChT binding [61]. $\left[{ }^{18} \mathrm{~F}\right] \mathrm{FEOBV}$ PET is a significant advance over currently available presynaptic cholinergic imaging agents and may be a valuable tool to assess dysregulation of the cholinergic system in $\mathrm{AD}$ and parkinsonian patients.

\section{Postsynaptic cholinergic dysfunction in Alzheimer's disease}

Previous PET studies using $\left[{ }^{11} \mathrm{C}\right]$ nicotine have shown significant reductions in nAChR binding in the frontal cortex, temporal cortex and hippocampus of patients with moderate $\mathrm{AD}$ $[62,63]$. Similar to AChE activity, decreases in cortical nAChR expression as measured by $\left[{ }^{11} \mathrm{C}\right]$ nicotine are associated with attention deficit but not episodic memory impairment [32]. These $\left[{ }^{11} \mathrm{C}\right]$ nicotine studies, however, were hindered by high levels of nonspecific binding, rapid metabolism, and washout from the brain, as well as a strong dependence on cerebral blood flow $[64,65]$. More recently, new PET and SPECT radioligands have been developed to target $\alpha_{4} \beta_{2}$ nAChR. Post-mortem autoradiography studies have shown that $\alpha_{4} \beta_{2} \mathrm{nAChR}$ is the most affected receptor subtype in $\mathrm{AD}$, with reductions of up to $50 \%$ in the neocortex, entorhinal cortex and hippocampus [12, 66, 67]. [ $\left.{ }^{123} \mathrm{I}\right] 5$-iodo-3-[2(S)-2azetidinylmethoxy $]$ pyridine $\left(\left[{ }^{123} \mathrm{I}\right] 5 \mathrm{IA}\right)$ SPECT has shown significant reductions in $\alpha_{4} \beta_{2} \mathrm{nAChR}$ in the frontal cortex, striatum, right medial temporal lobe and pons of $\mathrm{AD}$ patients [34]. $\left[{ }^{123} \mathrm{I}\right] 5 \mathrm{IA}$ binding is also significantly reduced in the medial temporal cortex of patients with amnestic mild cognitive impairment (MCI) and $\alpha_{4} \beta_{2} \mathrm{nAChR}$ decreases correlated 
Table 2 Cholinergic PET and SPECT studies using postsynaptic cholinergic markers in dementia spectrum disorders

\begin{tabular}{|c|c|c|c|c|c|}
\hline Radiotracer & Target & Reference & $\begin{array}{l}\text { Imaging } \\
\text { technique }\end{array}$ & Subjects & Main findings \\
\hline$\left[{ }^{11} \mathrm{C}\right] \mathrm{NMPB}$ & $\mathrm{mAChR}$ & {$[30]$} & PET & 7 PSP, 12 PD, 8 HC & $\begin{array}{l}\text { Significant increase in mAChR in frontal cortex in PD ( } 22 \%) \text {. } \\
\text { No significant change in any cortical region in PSP. }\end{array}$ \\
\hline$\left[{ }^{123} \mathrm{I}\right] \mathrm{QNB}$ & $\mathrm{mAChR}$ & {$[31]$} & SPECT & $25 \mathrm{PDD}, 14 \mathrm{DLB}, 24 \mathrm{HC}$ & $\begin{array}{l}\text { Significant increase in mAChR in right occipital lobe in DLB, } \\
\text { occipital lobes bilaterally in PDD; no significant difference } \\
\text { between DLB and PDD. Significant reduction in mAChR } \\
\text { expression in frontal and temporal lobes in PDD, nonsignificant } \\
\text { in DLB. }\end{array}$ \\
\hline$\left[{ }^{11} \mathrm{C}\right]$ Nicotine & $\mathrm{nAChR}$ & {$[32]$} & PET & $27 \mathrm{AD}, 36 \mathrm{HC}$ & $\begin{array}{l}\text { Significant correlation between cortical } \mathrm{nAChR} \text { expression and } \\
\text { Digit Symbol test score, as well as Trail Making Test A score. }\end{array}$ \\
\hline$\left[{ }^{123} \mathrm{I}\right] 5 \mathrm{IA}$ & $\alpha 4 \beta 2 \mathrm{nAChR}$ & [33] & SPECT & $10 \mathrm{PD}, 15 \mathrm{HC}$ & $\begin{array}{l}\text { Significant widespread reduction in cortical and subcortical } \\
\alpha 2 \beta 4 \text { nAChR levels in PD }(-10 \%) \text {; highest in thalamus } \\
(-15 \%) \text {, parietal cortex }(-9 \%) \text { and temporal cortex } \\
(-8 \%) \text {; lowest in frontal cortex }(-5 \%) \text { and occipital } \\
\text { cortex }(-3 \%) \text {. No significant change in K1 (index of } \\
\text { radiotracer delivery). }\end{array}$ \\
\hline$\left[{ }^{123} \mathrm{I}\right] 5 \mathrm{IA}$ & $\alpha 4 \beta 2 \mathrm{nAChR}$ & {$[34]$} & SPECT & $16 \mathrm{AD}, 16 \mathrm{HC}$ & $\begin{array}{l}\text { Significant reductions in } \alpha 2 \beta 4 \mathrm{nAChR} \text { expression in frontal, } \\
\text { striatal, right medial temporal and pontine regions in } \mathrm{AD} \text {. }\end{array}$ \\
\hline$\left[{ }^{123} \mathrm{I}\right] 5 \mathrm{IA}$ & $\alpha 4 \beta 2 \mathrm{nAChR}$ & {$[35]$} & SPECT & $10 \mathrm{PD}, 10 \mathrm{HC}$ & $\begin{array}{l}\text { Significant reductions in brainstem and frontal cortex } \alpha 2 \beta 4 \\
\text { nAChR levels in PD }(-20-25 \%) \text {. Significant negative } \\
\text { correlation between high daily dose of dopamine agonist } \\
\text { and tracer binding in cerebellum and temporal, parietal } \\
\text { and occipital cortices. }\end{array}$ \\
\hline$\left[{ }^{18} \mathrm{~F}\right] 2 \mathrm{FA}$ & $\alpha 4 \beta 2 \mathrm{nAChR}$ & {$[36]$} & PET & $15 \mathrm{AD}, 14 \mathrm{HC}$ & $\begin{array}{l}\text { No significant change in } \alpha 2 \beta 4 \mathrm{nAChR} \text { in early AD compared } \\
\text { to } \mathrm{HC} \text {; suggestive of } \mathrm{nAChR} \text { preservation in early stages } \\
\text { of } \mathrm{AD} \text {. }\end{array}$ \\
\hline$\left[{ }^{123} \mathrm{I}\right] 5 \mathrm{IA}$ & $\alpha 4 \beta 2 \mathrm{nAChR}$ & {$[37]$} & SPECT & $15 \mathrm{DLB}, 16 \mathrm{HC}$ & $\begin{array}{l}\text { Significant reduction in } \alpha 2 \beta 4 \mathrm{nAChR} \text { levels in frontal, temporal, } \\
\text { cingulate cortices and striatum. Significant increase in occipital } \\
\text { cortex expression, correlated with visual hallucinations. }\end{array}$ \\
\hline$\left[{ }^{18} \mathrm{~F}\right] 2 \mathrm{FA}$ & $\alpha 4 \beta 2 \mathrm{nAChR}$ & {$[38]$} & PET & $17 \mathrm{AD}, 6 \mathrm{MCI}, 10 \mathrm{HC}$ & $\begin{array}{l}\text { Significant reduction in } \alpha 2 \beta 4 \mathrm{nAChR} \text { expression in thalamus, } \\
\text { striatum, cerebellum and cortex of both } \mathrm{AD} \text { and MCI patients. } \\
\text { Significant negative correlation between }\left[{ }^{18} \mathrm{~F}\right] 2 \mathrm{FA} \text { binding } \\
\text { and level of cognitive impairment. }\end{array}$ \\
\hline$\left[{ }^{18} \mathrm{~F}\right] 2 \mathrm{FA}$ & $\alpha 4 \beta 2 \mathrm{nAChR}$ & [39] & PET & $13 \mathrm{PD}, 6 \mathrm{HC}$ & $\begin{array}{l}\text { Significant reduction in } \alpha 2 \beta 4 \mathrm{nAChR} \text { in striatum }(-10 \%) \\
\text { and substantia nigra }(-14.9 \%) \text { in PD. }\end{array}$ \\
\hline$\left[{ }^{18} \mathrm{~F}\right] 2 \mathrm{FA}$ & $\alpha 4 \beta 2 \mathrm{nAChR}$ & {$[40]$} & PET & $22 \mathrm{PD}, 9 \mathrm{HC}$ & $\begin{array}{l}\text { Significant reduction in } \alpha 2 \beta 4 \mathrm{nAChR} \text { levels, most pronounced } \\
\text { in the midbrain, pons, anterior cingulate and frontoparietal } \\
\text { cortices, and cerebellum. Significant correlation between } \\
{\left[{ }^{18} \mathrm{~F}\right] 2 \mathrm{FA} \text { binding in the anterior cingulate and occipital cortices }} \\
\text { and depression. Significant correlation between }\left[{ }^{18} \mathrm{~F}\right] 2 \mathrm{FA} \\
\text { binding in the midbrain, pons and cerebellum and cognitive } \\
\text { impairment. }\end{array}$ \\
\hline$\left[{ }^{123} \mathrm{I}\right] 5 \mathrm{IA}$ & $\alpha 4 \beta 2 \mathrm{nAChR}$ & {$[41]$} & SPECT & $12 \mathrm{AD}, 10 \mathrm{MCI}, 10 \mathrm{HC}$ & $\begin{array}{l}\text { No significant difference in } \alpha 2 \beta 4 \mathrm{nAChR} \text { levels in any brain } \\
\text { region investigated (frontal, parietal, anterior cingulate, } \\
\text { temporal and occipital cortices, thalamus, striatum, cerebellum). }\end{array}$ \\
\hline$\left[{ }^{123} \mathrm{I}\right] 5 \mathrm{IA}$ & $\alpha 4 \beta 2 \mathrm{nAChR}$ & {$[42]$} & SPECT & $10 \mathrm{MCI}, 10 \mathrm{HC}$ & $\begin{array}{l}\text { Significant reduction in tracer binding in medial temporal } \\
\text { cortex. Significant correlation between }\left[{ }^{123} \mathrm{I}\right] 5 \mathrm{I} \text { A uptake in } \\
\text { left temporoparietal cortex, bilateral temporolimbic areas and } \\
\text { right parahippocampal gyrus and level of cognitive impairment. }\end{array}$ \\
\hline$\left[{ }^{18} \mathrm{~F}\right] 2 \mathrm{FA}$ & $\alpha 4 \beta 2 \mathrm{nAChR}$ & [43] & PET & $20 \mathrm{AD}, 25 \mathrm{HC}$ & $\begin{array}{l}\text { Significant reduction in } \alpha 2 \beta 4 \mathrm{nAChR} \text { availability in thalamus, } \\
\text { caudate, and prefrontal cortex, and medial and lateral temporal } \\
\text { cortices. Significant positive correlation between }\left[{ }^{18} \mathrm{~F}\right] 2 \mathrm{FA} \\
\text { uptake in medial frontal cortex and nucleus basalis of Meynert } \\
\text { and Frontal Assessment Battery test scores in AD patients. } \\
\text { Significant negative correlation between amyloid- } \beta \text { load and } \\
\alpha 2 \beta 4 \mathrm{nAChR} \text { expression in frontal cortex. }\end{array}$ \\
\hline
\end{tabular}

$A D$ Alzheimer's disease, $D L B$ dementia with Lewy bodies, $H C$ healthy control, $m A C h R$ muscarinic acetylcholine receptor, $M C I$ mild cognitive impairment, $n A C h R$ nicotinic acetylcholine receptor, $P D$ Parkinson's disease, $P D D$ Parkinson's disease dementia, $P S P$ progressive supranuclear palsy 
with cognitive decline [42]. However, other studies have yielded contrasting results, finding no changes in $\alpha_{4} \beta_{2}$ $\mathrm{nAChR}$ binding in cortical and thalamic regions of patients with early AD or MCI compared to healthy controls [36, 41]. This discrepancy may be due to the different severities of cognitive impairment of the subjects studied and different methodologies in assessing $\alpha_{4} \beta_{2}$ nAChR expression.

PET with 2-[ $\left[{ }^{18} \mathrm{~F}\right] \mathrm{F}-\mathrm{A}-85380\left(\left[{ }^{18} \mathrm{~F}\right] 2 \mathrm{FA}\right)$, a radioligand selective for $\alpha_{4} \beta_{2} n A C h R$, has shown significant reductions in nAChR availability in the hippocampus, and frontal, temporal and parietal cortices of $\mathrm{AD}$ patients, which furthermore correlated with the level of cognitive impairment [38]. Another $\left[{ }^{18} \mathrm{~F}\right] 2 \mathrm{FA}$ study showed significantly reduced $\alpha_{4} \beta_{2} \mathrm{nAChR}$ expression in the medial frontal cortex and nucleus basalis of Meynert in AD patients, which were correlated with Frontal Assessment Battery scores, suggesting that in vivo $\alpha_{4} \beta_{2}$ $\mathrm{nAChR}$ plays role in those specific functions that may be different from episodic memory [43]. Furthermore, a negative correlation between $\alpha_{4} \beta_{2} n A C h R$ availability and $A \beta$ load (measured by $\left[{ }^{11} \mathrm{C}\right]$ Pittsburgh compound $\mathrm{B}$ ) was found in the same brain regions, suggesting that $A \beta$ deposition may induce degeneration of cholinergic neurons [43]. However, $\left[{ }^{18} \mathrm{~F}\right] 2 \mathrm{FA}$ exhibits slow brain distribution kinetics and relatively low binding potentials $(\leq 0.6-0.8)$ in extrathalamic regions including the cortex which are of high importance in studying neurodegenerative diseases [68]. In recent years, major effort has focused on the development of new $\alpha_{4} \beta_{2}$ nAChR PET radioligands with faster regional brain kinetics than $\left[{ }^{18} \mathrm{~F}\right] 2 \mathrm{FA}$ that will enable further imaging studies in dementia spectrum disorders [69].

\section{Cholinergic imaging in assessing Alzheimer's disease treatment}

Cholinergic PET imaging techniques have also been employed to assess the efficacy of medications. PET with $\left[{ }^{11} \mathrm{C}\right] \mathrm{PMP}$ has shown $19-39 \%$ inhibition of cortical AChE activity following donepezil treatment in $\mathrm{AD}$ patients [70,71] whereas $28-39 \% \mathrm{AChE}$ inhibition has been observed after donepezil and rivastigmine in the frontal temporal and parietal regions of AD patients using $\left[{ }^{11} \mathrm{C}\right] \mathrm{MP} 4 \mathrm{~A}$ PET $[72,73]$. Kadir and colleagues [74] investigated the effect of galantamine, a cholinesterase inhibitor, on AChE activity and nicotine binding to $\mathrm{nAChR}$ in $\mathrm{AD}$ patients. They found significant reductions in cortical $\left[{ }^{11} \mathrm{C}\right] \mathrm{PMP}$ following galantamine treatment at 3 weeks, and 3 and 12 months compared with baseline [74]. These findings suggest that galantamine treatment is able to increase ACh concentrations in the synaptic cleft resulting in increased cholinergic neurotransmission. No significant changes in $\left[{ }^{11} \mathrm{C}\right]$ nicotine binding were found following galantamine treatment [74]. Galantamine acts on $\mathrm{nAChR}$ as an allosterically potentiating ligand [75], thereby sensitizing the receptors, which in turn causes $\mathrm{AChR}$ upregulation to maintain a baseline level of signalling.

\section{Cholinergic system in parkinsonian dementias}

Parkinson's disease (PD) is a chronic neurodegenerative disorder characterized pathologically by degeneration of dopaminergic neurons in the substantia nigra pars compacta and formation of $\alpha$-synuclein proteinaceous intraneuronal inclusions referred to as Lewy bodies and Lewy neurites [76-78]. In addition to classical motor symptoms, non-motor features such as cognitive decline, are a very important aspect of the disease, because they add significantly to the burden on patients and caregivers $[79,80]$. PD patients carry a sixfold increased risk for dementia compared to the general population, with approximately $80 \%$ of patients developing PD dementia (PDD) over the course of the disease [81, 82]. MCI in PD also appears to be common, occurring in $20 \%$ to $50 \%$ of PD patients, even at the time of PD diagnosis and prior to initiation of dopaminergic therapy [83, 84]. Dementia with Lewy bodies (DLB) is characterized by fluctuating cognitive and attentional deficits, recurrent visual hallucinations and parkinsonism, and is the second most common cause of degenerative dementia, accounting for $15-25 \%$ of cases [85]. Evidence for the involvement of the cholinergic system in the development of PDD and DLB has been provided by postmortem studies, which have shown decreased AChE activity and nAChR density in cortical and subcortical brain tissue of PDD and DLB patients [86-92].

\section{Presynaptic cholinergic dysfunction in parkinsonian dementias}

PET studies using $\left[{ }^{11} \mathrm{C}\right] \mathrm{MP} 4 \mathrm{~A}$ and $\left[{ }^{11} \mathrm{C}\right] \mathrm{PMP}$ have demonstrated mild to moderate decreases in cortical AChE activity in PD patients without dementia, and severe decreases in PDD and DLB patients $[21,23,26]$. Using SPECT with $\left[{ }^{123} \mathrm{I}\right] \mathrm{IBVM}$, Kuhl et al. [16] demonstrated that whilst in PD without dementia, VAChT levels are reduced only in the parietal and occipital cortices, in PDD, major losses are seen throughout the entire cortex, suggesting a greater and more widespread presynaptic cholinergic dysfunction in PDD patients. Loss of AChE activity occurs in early stages of the disease, with de novo PD patients showing significant (12\%) AChE losses in the medial occipital cortex [24]. Differences in AChE activity between early and advanced PD are nonsignificant, however, suggesting that cholinergic dysfunction occurs early, but does not progress with the disease [24]. Moreover, loss of cortical AChE activity as measured by $\left[{ }^{11} \mathrm{C}\right] \mathrm{PMP}$ is correlated with worse performance in working memory and attention tests but not with the severity of motor symptoms [23]. A relationship between striatal $\left[{ }^{18} \mathrm{~F}\right]$ FDOPA uptake and cortical $\left[{ }^{11} \mathrm{C}\right] \mathrm{MPA}$ reduction has been found in PDD patients, suggesting that cognitive decline in PD occurs when the disease spreads from nigral neurons to the cortex, leading to a cholinergic dysfunction in this region [21]. 
Cholinergic dysfunction is higher in PDD patients than in AD patients with a similar degree of cognitive impairment (MMSE score 22.8 and 22.2, respectively) suggesting that the mechanisms underlying cognitive decline in PD and AD have different pathogeneses [19]. In contrast to the cholinergic system in $\mathrm{AD}$, which was spared $(0.7 \%$ reduction $)$, thalamic AChE activity was found to be decreased by $19.8 \%$ in PDD patients [28].

Cortical AChE activity differs between patients with PD and those with progressive supranuclear palsy (PSP) [18, 25]. PD patients show significant decreases in cortical $\left[{ }^{11} \mathrm{C}\right] \mathrm{MP} 4 \mathrm{~A}$ uptake, whereas PSP patients show significant reductions only in the thalamus [18]. Therefore, a thalamic/ cortical $\left[{ }^{11} \mathrm{C}\right] \mathrm{MP} 4 \mathrm{~A}$ binding ratio may be useful in distinguishing between PD and PSP. A SPECT study using an $\left[{ }^{123} \mathrm{I}\right] \mathrm{IBVM}$ ligand found that VAChT levels are significantly lower in the thalamus and anterior cingulate cortex of PSP patients compared to healthy controls, and that thalamic cholinergic dysfunction is inversely correlated with disease duration [29]. This is in line with the findings of similar PET studies reported previously, that show a preferential cholinergic denervation in the thalamus of PSP patients [83]. VAChT levels, however, are unaffected in the striatum of PSP patients [29]. This differs from PD pathology, in which cholinergic neurons in the striatum are affected, suggesting a possible role of cholinergic imaging markers in aiding the differential diagnosis of these two clinically similar diseases [29].

In other atypical parkinsonisms such as multiple system atrophy, cortical AChE activity decreases have been found to be similar to those seen in PD patients $(-14.6 \%$ and $-15.3 \%$, respectively) [25]. Hirano et al. [27] investigated differences in AChE activity in patients with PSP, corticobasal degeneration (CBD) and frontotemporal dementia (FTD) using both voxel-based and volume of interest analysis. Statistical parametric mapping analysis showed significant AChE decreases in the paracentral region, frontal, parietal and occipital cortices in CBD patients and in the paracentral region and thalamus in PSP patients [27]. FTD patients showed no significant differences in AChE activity compared to the control group. Volume of interest analysis showed significant decreases in thalamic AChE activity only in PSP patients. Thus, cholinergic dysfunction occurs in CBD and PSP, although involving different brain regions, but it was not observed in FTD patients, which may explain why AChE inhibitors are ineffective for this condition [93].

\section{Postsynaptic cholinergic dysfunction in parkinsonian dementias}

Post-mortem studies have shown that cortical mAChR density is altered in PDD and DLB samples [94, 95]. An in vivo PET study with $N-\left[{ }^{11} \mathrm{C}\right]$ methyl-4-piperidyl benzilate ([ $\left.\left[{ }^{11} \mathrm{C}\right] \mathrm{NMPB}\right)$, a marker for $\mathrm{mAChR}$, demonstrated increased
mAChR levels in the frontal cortex of PD patients, probably due to denervation hypersensitivity caused by loss of the ascending cholinergic system in frontal areas [30]. Contrastingly, in PSP patients, cortical and thalamic $\left[{ }^{11} \mathrm{C}\right] \mathrm{NMPB}$ binding was preserved [30]. A SPECT study using $\left[{ }^{123} \mathrm{I}\right]$ iodo-quinuclidinyl benzilate $\left(\left[{ }^{123} \mathrm{I}\right] \mathrm{QNB}\right)$, another marker for $\mathrm{mAChR}$, showed significant increases in $\mathrm{mAChR}$ in the occipital lobe in both PDD and DLB, which may be the substrate of visual disturbances in these diseases [31]. Furthermore, there was significantly lower $\left[{ }^{123} \mathrm{I}\right] \mathrm{QNB}$ binding in the frontal and temporal lobes of PDD patients than in DLB patients. $\left[{ }^{11} \mathrm{C}\right] \mathrm{NMPB}$ and $\left[{ }^{123} \mathrm{I}\right] \mathrm{QNB}$ are high-affinity mAChR antagonists with similar chemical structures and regional brain distributions [96-98]. Both radioligands penetrate the blood-brain barrier efficiently but nonspecifically in relation to mAChR subtype [99].

$\left[{ }^{123} \mathrm{I}\right]$ IA SPECT studies have shown $10-25 \%$ reductions in $\mathrm{nAChR}$ levels in cortical and subcortical regions of PD patients [33, 95], with the largest decreases observed in the thalamus, and parietal and temporal cortices [33]. A $\left[{ }^{18} \mathrm{~F}\right] 2 \mathrm{FA}$ PET study showed significant reductions in $\alpha_{4} \beta_{2} \mathrm{nAChR}$ availability in various regions in PD patients, including the frontoparietal and anterior cingulate cortices, midbrain, pons and cerebellum, with the highest reduction in the left parietal cortex [40]. Furthermore, $\alpha_{4} \beta_{2}$ nAChR loss correlated with depression and cognitive decline as measured by the MMSE, the DemTect Scale, the Clock Drawing test, delayed recall of figures of the CERAD (Consortium to Establish a Registry for Alzheimer's Disease) battery, and the Trail Making test [40]. In nondemented PD patients, cortical and subcortical $\left[{ }^{123}\right.$ I]5IA decreases correlated with worse performance In the Boston Naming test and Word List Intrusions test, two specific tests for detection of word-finding difficulties, learning capacity and memory for language information [98]. Decreases in $\left[{ }^{18} \mathrm{~F}\right] 2 \mathrm{FA}$ uptake were also found in the striatum $(-10 \%)$ and substantia nigra ( $-14.9 \%)$ of PD patients, but did not correlate with dopaminergic function as measured by $\left[{ }^{18} \mathrm{~F}\right] \mathrm{F}-\mathrm{DOPA}$, nor with clinical severity [39].

$\left[{ }^{123}\right.$ I] 5IA SPECT has shown significant reductions in $\alpha_{4} \beta_{2}$ $\mathrm{nAChR}$ binding in the frontal, temporal and cingulate cortex, as well as in the striatum of DLB patients [37]. In the occipital cortex, however, $\alpha_{4} \beta_{2}$ nAChR levels were increased and correlated with visual hallucinations experienced by DLB patients, suggesting cholinergic dysfunction in the occipital lobe as a substrate of visual hallucinations. Because $\alpha_{4} \beta_{2}$ nAChRs are located in some regions presynaptically on both cholinergic and noncholinergic terminals [101], some difficulties may arise in the interpretation of $\mathrm{nAChR}$ imaging studies. In PD, significantly decreased $\alpha_{4} \beta_{2} \mathrm{nAChR}$ levels may be a result of $\mathrm{nAChR}$ loss on degenerated presynaptic nigrostriatal dopaminergic neurons. A post-mortem study has shown that loss of striatal nAChR binding closely parallels the loss of nigrostriatal dopaminergic markers in PD brain tissue [102]. 
Postsynaptic nAChR receptors may show a compensatory increase, no change, or a decrease due to degeneration of noncholinergic systems (e.g. noradrenergic, serotoninergic, glutamatergic) to which the nAChRs are coupled [37, 102]. Further studies combining cholinergic and noncholinergic radioligands may aid in elucidating the $\mathrm{nAChR}$ alteration patterns in parkinsonian disorders.

\section{Conclusion}

Cholinergic dysfunction has a pivotal role in the pathophysiology of cognitive decline. Given the wide variety of available markers for the cholinergic system, molecular imaging techniques provide a valuable tool to investigate pathophysiological mechanisms, and monitor progression and response to treatments in $\mathrm{AD}$ and parkinsonian dementia. The largest drawback of this technology, its cost, will hopefully be improved by its widening use as it becomes increasingly clear that PET and SPECT imaging holds much potential for gleaning important information about the pathology of dementia. Much remains to be learned about cholinergic dysfunction in AD, PD and related disorders. PET studies combining presynaptic and postsynaptic radioligands may be useful in unravelling alterations of cholinergic neurotransmission. Moreover, it has been suggested that the $\alpha 7 \mathrm{nAChR}$ subtype may have a neuroprotective role by modulating the neurotrophic system crucial for the maintenance of cholinergic neuron integrity, and also by stimulating signal transduction pathways that support neuron survival [103]. In $\mathrm{AD}, \alpha 7 \mathrm{nAChR}$ may modulate $\beta$-amyloid-induced pathology [104], and deletion of the $\alpha 7 \mathrm{nAChR}$ gene has shown to improve cognitive impairment in animal models of AD [105]. Further PET studies using radioligands specific to the $\alpha 7$ nAChR such as $\left[{ }^{18} \mathrm{~F}\right] \mathrm{ASEM}[106,107]$ are needed to determine the relationship between $\alpha 7 \mathrm{nAChR}$ and AD pathology.

\section{Compliance with ethical standards}

\section{Conflicts of interest None.}

Ethical approval This article does not describe any studies with human participants performed by any of the authors.

Open Access This article is distributed under the terms of the Creative Commons Attribution 4.0 International License (http:// creativecommons.org/licenses/by/4.0/), which permits unrestricted use, distribution, and reproduction in any medium, provided you give appropriate credit to the original author(s) and the source, provide a link to the Creative Commons license, and indicate if changes were made.

\section{References}

1. WHO. Dementia. Fact sheet no. 362. Geneva: World Health Organization 2015
2. Prince M, Bryce R, Albanese E, Wimo A, Ribeiro W, Ferri CP. The global prevalence of dementia: a systematic review and metaanalysis. Alzheimers Dement. 2013;9:63-75.e2.

3. Berger-Sweeney J. The cholinergic basal forebrain system during development and its influence on cognitive processes: important questions and potential answers. Neurosci Biobehav Rev. 2003;27:401-11.

4. Schliebs R, Arendt T. The cholinergic system in aging and neuronal degeneration. Behav Brain Res. 2011;221:555-63.

5. Pahapill PA, Lozano AM. The pedunculopontine nucleus and Parkinson's disease. Brain. 2000;123(Pt 9):1767-83.

6. Mesulam M, Mash D, Hersh L, Bothwell M, Geula C. Cholinergic innervation of the human striatum, globus pallidus, subthalamic nucleus, substantia nigra, and red nucleus. J Comp Neurol. 1992;323:252-68.

7. Enna SJ, Bennett Jr JP, Bylund DB, Creese I, Burt DR, Charness $\mathrm{ME}$, et al. Neurotransmitter receptor binding: regional distribution in human brain. J Neurochem. 1977;28:233-6.

8. Davies P, Verth AH. Regional distribution of muscarinic acetylcholine receptor in normal and Alzheimer's-type dementia brains. Brain Res. 1977;138:385-92.

9. Yamamura HI, Kuhar MJ, Greenberg D, Snyder SH. Muscarinic cholinergic receptor binding: regional distribution in monkey brain. Brain Res. 1974;66:541-6.

10. Shimohama S, Taniguchi T, Fujiwara M, Kameyama M. Biochemical characterization of the nicotinic cholinergic receptors in human brain: binding of $(-)[3 \mathrm{H}]$ nicotine. J Neurochem. 1985;45:604-60.

11. Perry EK, Court JA, Johnson M, Piggott MA, Perry RH. Autoradiographic distribution of $[3 \mathrm{H}]$ nicotine binding in human cortex: relative abundance in subicular complex. J Chem Neuroanat. 1992;5:399-405.

12. Flynn DD, Mash DC. Characterization of L- $[3 \mathrm{H}]$ nicotine binding in human cerebral cortex: comparison between Alzheimer's disease and the normal. J Neurochem. 1986;47:1948-54.

13. Bartus RT, Dean RL, Beer 3rd B, Lippa AS. The cholinergic hypothesis of geriatric memory dysfunction. Science. 1982;217:40814.

14. Perry EK, Gibson PH, Blessed G, Perry RH, Tomlinson BE. Neurotransmitter enzyme abnormalities in senile dementia: choline acetyltransferase and glutamic acid decarboxylase activities in necropsy brain tissue. J Neurol Sci. 1977;34:247-65.

15. Davis KL, Mohs RC, Marin D, Purohit DP, Perl DP, Lantz M, et al. Cholinergic markers in elderly patients with early signs of Alzheimer disease. JAMA. 1999;281:1401-6.

16. Kuhl DE, Minoshima S, Fessler JA, Ficaro EP, Wieland DM, Koeppe RA, et al. In vivo mapping of cholinergic terminals in normal aging, Alzheimer's disease, and Parkinson's disease. Ann Neurol. 1996;40:399-410.

17. Kuhl DE, Koeppe RA, Minoshima S, Snyder SE, Ficaro EP, Foster NL, et al. In vivo mapping of cerebral acetylcholinesterase activity in aging and Alzheimer's disease. Neurology. 1999;52: 691-9.

18. Shinotoh H, Namba H, Yamaguchi M, Fukushi K, Nagatsuka SI, Iyo $\mathrm{M}$, et al. Positron emission tomographic measurement of acetylcholinesterase activity reveals differential loss of ascending cholinergic systems in Parkinson's disease and progressive supranuclear palsy. Ann Neurol. 1999;46:62-9.

19. Bohnen NI, Kaufer DI, Ivanco LS, Lopresti B, Koeppe RA, Davis $\mathrm{JG}$, et al. Cortical cholinergic function is more severely affected in parkinsonian dementia than in Alzheimer disease: an in vivo positron emission tomographic study. Arch Neurol. 2003;60:1745-8.

20. Bohnen NI, Kaufer DI, Hendrickson R, Ivanco LS, Lopresti B, Davis JG, et al. Cognitive correlates of alterations in acetylcholinesterase in Alzheimer's disease. Neurosci Lett. 2005;380:127-32. 
21. Hilker R, Thomas AV, Klein JC, Weisenbach S, Kalbe E, Burghaus L, et al. Dementia in Parkinson disease: functional imaging of cholinergic and dopaminergic pathways. Neurology. 2005;65:1716-22.

22. Eggers C, Herholz K, Kalbe E, Heiss WD. Cortical acetylcholine esterase activity and ApoE4- genotype in Alzheimer disease. Neurosci Lett. 2006;408:46-50.

23. Bohnen NI, Kaufer DI, Hendrickson R, Ivanco LS, Lopresti BJ, Constantine GM, et al. Cognitive correlates of cortical cholinergic denervation in Parkinson's disease and parkinsonian dementia. J Neurol. 2006;253:242-7.

24. Shimada H, Hirano S, Shinotoh H, Aotsuka A, Sato K, Tanaka N, et al. Mapping of brain acetylcholinesterase alterations in Lewy body disease by PET. Neurology. 2009;73:273-8.

25. Gilman S, Koeppe RA, Nan B, Wang CN, Wang X, Junck L, et al. Cerebral cortical and subcortical cholinergic deficits in parkinsonian syndromes. Neurology. 2010;74:1416-23.

26. Klein JC, Eggers C, Kalbe E, Weisenbach S, Hohmann C, Vollmar $\mathrm{S}$, et al. Neurotransmitter changes in dementia with Lewy bodies and Parkinson disease dementia in vivo. Neurology. 2010;74:88592.

27. Hirano S, Shinotoh H, Shimada H, Aotsuka A, Tanaka N, Ota T, et al. Cholinergic imaging in corticobasal syndrome, progressive supranuclear palsy and frontotemporal dementia. Brain. 2010;133: 2058-68.

28. Kotagal V, Müller MLTM, Kaufer DI, Koeppe RA, Bohnen NI. Thalamic cholinergic innervation is spared in Alzheimer disease compared to parkinsonian disorders. Neurosci Lett. 2012;514: 169-72.

29. Mazère J, Meissner WG, Mayo W, Sibon I, Lamare F, Guilloteau $\mathrm{D}$, et al. Progressive supranuclear palsy: in vivo SPECT imaging of presynaptic vesicular acetylcholine transporter with [123I]iodobenzovesamicol. Radiology. 2012;265:537-43.

30. Asahina M, Suhara T, Shinotoh H, Inoue O, Suzuki K, Hattori T. Brain muscarinic receptors in progressive supranuclear palsy and Parkinson's disease: a positron emission tomographic study. J Neurol Neurosurg Psychiatry. 1998;65:155-63.

31. Colloby SJ, Pakrasi S, Firbank MJ, Perry EK, Piggott MA, Owens $\mathrm{J}$, et al. In vivo SPECT imaging of muscarinic acetylcholine receptors using (R,R)123I-QNB in dementia with Lewy bodies and Parkinson's disease dementia. Neuroimage. 2006;33:423-9.

32. Kadir A, Almkvist $\mathrm{O}$, Wall A, Långström B, Nordberg A. PET imaging of cortical $11 \mathrm{C}$-nicotine binding correlates with the cognitive function of attention in Alzheimer's disease. Psychopharmacology. 2006;188:509-20.

33. Fujita M, Ichise M, Zoghbi SS, Liow JS, Ghose S, Vines DC, et al. Widespread decrease of nicotinic acetylcholine receptors in Parkinson's disease. Ann Neurol. 2006;59:174-7.

34. O'Brien JT, Colloby SJ, Pakrasi S, Perry EK, Pimlott SL, Wyper DJ, et al. Alpha4beta2 nicotinic receptor status in Alzheimer's disease using 123I-5IA-85380 single-photon-emission computed tomography. J Neurol Neurosurg Psychiatry. 2007;78:356-62.

35. Oishi N, Hashikawa K, Yoshida H, Ishizu K, Ueda M, Kawashima $\mathrm{H}$, et al. Quantification of nicotinic acetylcholine receptors in Parkinson's disease with 123I-5IA SPECT. J Neurol Sci. 2007;256:52-60.

36. Ellis JR, Villemagne VL, Nathan PJ, Mulligan RS, Gong SJ, Chan $\mathrm{JG}$, et al. Relationship between nicotinic receptors and cognitive function in early Alzheimer's disease: a 2-[18F]fluoro-A-85380 PET study. Neurobiol Learn Mem. 2008;90:404-12.

37. O’Brien JT, Colloby SJ, Pakrasi S, Perry EK, Pimlott SL, Wyper DJ, et al. Nicotinic $\alpha 4 \beta 2$ receptor binding in dementia with Lewy bodies using 123I-5IA-85380 SPECT demonstrates a link between occipital changes and visual hallucinations. Neuroimage. 2008;40:1056-63.
38. Sabri O, Kendziorra K, Wolf H, Gertz H-J, Brust P. Acetylcholine receptors in dementia and mild cognitive impairment. Eur J Nucl Med Mol Imaging. 2008;35:30-45.

39. Kas A, Bottlaender M, Gallezot JD, Vidailhet M, Villafane G, Grégoire MC, et al. Decrease of nicotinic receptors in the nigrostriatal system in Parkinson's disease. J Cereb Blood Flow Metab. 2009;29:1601-8.

40. Meyer PM, Strecker K, Kendziorra K, Becker G, Hesse S, Woelpl $\mathrm{D}$, et al. Reduced $\alpha 4 \beta 2 *$-nicotinic acetylcholine receptor binding and its relationship to mild cognitive and depressive symptoms in Parkinson disease. Arch Gen Psychiatry. 2009;66:866-77.

41. Mitsis EM, Reech KM, Bois F, Tamagnan GD, Macavoy MG, Seibyl JP, et al. 123I-5-IA-85380 SPECT imaging of nicotinic receptors in Alzheimer disease and mild cognitive impairment. $\mathrm{J}$ Nucl Med. 2009;50:1455-63.

42. Terrière E, Dempsey MF, Herrmann LL, Tierney KM, Lonie JA, O'Carroll RE, et al. 5-(123)I-A-85380 binding to the $\alpha 4 \beta 2$ nicotinic receptor in mild cognitive impairment. Neurobiol Aging. 2010;31:1885-93.

43. Okada H, Ouchi Y, Ogawa M, Futatsubashi M, Saito Y, Yoshikawa E, et al. Alterations in alpha4beta2 nicotinic receptors in cognitive decline in Alzheimer's aetiopathology. Brain. 2013;136:3004-17.

44. Lobo A, Launer LJ, Fratiglioni L, Andersen K, Di Carlo A, Breteler MM, et al. Prevalence of dementia and major subtypes in Europe: A collaborative study of population-based cohorts. Neurologic Diseases in the Elderly Research Group. Neurology. 2000;54:S4-9.

45. Dugu M, Neugroschl J, Sewell M, Marin D. Review of dementia. Mt Sinai J Med. 2003;70:45-53.

46. Braak H, Braak E. Neuropathological stageing of Alzheimerrelated changes. Acta Neuropathol. 1991;82:239-59.

47. Masliah E, Mallory M, Alford M, DeTeresa R, Hansen LA, McKeel Jr DW, et al. Altered expression of synaptic proteins occurs early during progression of Alzheimer's disease. Neurology. 2001;56:127-9.

48. Spires-Jones TL, Hyman BT. The intersection of amyloid beta and tau at synapses in Alzheimer's disease. Neuron. 2014;82:756-71.

49. Davies P, Maloney AJF. Selective loss of central cholinergic neurons in Alzheimer's disease. Lancet. 1976;308:1403.

50. Perry EK, Tomlinson BE, Blessed G, Bergmann K, Gibson PH, Perry RH. Correlation of cholinergic abnormalities with senile plaques and mental test scores in senile dementia. Br Med J. 1978;2:1457-9.

51. Coyle JT, Price DL, DeLong MR. Alzheimer's disease: a disorder of cortical cholinergic innervation. Science. 1983;219:1184-90.

52. Bierer LM, Haroutunian V, Gabriel S, Knott PJ, Carlin LS, Purohit DP, et al. Neurochemical correlates of dementia severity in Alzheimer's disease: relative importance of the cholinergic deficits. J Neurochem. 1995;64:749-60.

53. Whitehouse PJ, Price DL, Struble RG, Clark AW, Coyle JT, Delon MR. Alzheimer's disease and senile dementia: loss of neurons in the basal forebrain. Science. 1982;215:1237-9.

54. Irie T, Fukushi K, Akimoto Y, Tamagami H, Nozaki T. Design and evaluation of radioactive acetylcholine analogs for mapping brain acetylcholinesterase (AChE) in vivo. Nucl Med Biol. 1994;21: 801-8.

55. Geula C, Mesulam MM. Systematic regional variations in the loss of cortical cholinergic fibers in Alzheimer's disease. Cereb Cortex. 1996;6:165-77.

56. Iyo M, Namba H, Fukushi K, Shinotoh H, Nagatsuka S, Suhara T, et al. Measurement of acetylcholinesterase by positron emission tomography in the brains of healthy controls and patients with Alzheimer's disease. Lancet. 1997;349:1805-9. 
57. Namba H, Iyo M, Shinotoh H, Nagatsuka S, Fukushi K, Irie T. Preserved acetylcholinesterase activity in aged cerebral cortex. Lancet. 1998;351:881-2.

58. Koeppe RA, Frey KA, Snyder SE, Meyer P, Kilbourn MR, Kuhl DE. Kinetic modeling of N-[11C]methylpiperidin-4-yl propionate: alternatives for analysis of an irreversible positron emission tomography trace for measurement of acetylcholinesterase activity in human brain. J Cereb Blood Flow Metab. 1999;19:1150-63.

59. Kuhl DE, Koeppe RA, Fessler JA, Minoshima S, Ackermann RJ, Carey JE, et al. In vivo mapping of cholinergic neurons in the human brain using SPECT and IBVM. J Nucl Med. 1994;35: 405-10.

60. Bird TD, Stranahan S, Sumi SM, Raskind M. Alzheimer's disease: choline acetyltransferase activity in brain tissue from clinical and pathological subgroups. Ann Neurol. 1983;14:284-93.

61. Petrou M, Frey KA, Kilbourn MR, Scott PJ, Raffel DM, Bohnen NI, et al. In vivo imaging of human cholinergic nerve terminals with (-)-5-(18)F-fluoroethoxybenzovesamicol: biodistribution, dosimetry, and tracer kinetic analyses. J Nucl Med. 2014;55: 396-404.

62. Nordberg A, Hartvig P, Lilja A, Viitanen M, Amberla K, Lundqvist $\mathrm{H}$, et al. Decreased uptake and binding of11Cnicotine in brain of Alzheimer patients as visualized by positron emission tomography. J Neural Transm Park Dis Dement Sect. 1990;2:215-24.

63. Nordberg A, Lundqvist H, Hartvig P, Lilja A, Långström B. Kinetic analysis of regional (S)(-)11C-nicotine binding in normal and Alzheimer brains in vivo assessment using positron emission tomography. Alzheimer Dis Assoc Disord. 1995;9:21-7.

64. Nybäck H, Halldin C, Åhlin A, Curvall M, Eriksson L. PET studies of the uptake of (S)- and (R)-[11C]nicotine in the human brain: difficulties in visualizing specific receptor binding in vivo. Psychopharmacology. 1994;115:31-6.

65. Nordberg A, Lundqvist H, Hartvig P, Andersson J, Johansson M, Hellström-Lindahl E, et al. Imaging of nicotinic and muscarinic receptors in Alzheimer's disease: effect of tacrine treatment. Dement Geriatr Cogn Disord. 1997;8:78-84.

66. Nordberg A, Winblad B. Reduced number of $[3 \mathrm{H}]$ nicotine and $[3 \mathrm{H}]$ acetylcholine binding sites in the frontal cortex of Alzheimer brains. Neurosci Lett. 1986;72:115-9.

67. Sabbagh MN, Shah F, Reid RT, Sue L, Connor DJ, Peterson LKN, et al. Pathologic and nicotinic receptor binding differences between mild cognitive impairment, Alzheimer disease, and normal aging. Arch Neurol. 2006;63:1771-6.

68. Horti AG, Villemagne VL. The quest for Eldorado: development of radioligands for in vivo imaging of nicotinic acetylcholine receptors in human brain. Curr Pharm Des. 2006;12:3877-900.

69. Horti AG, Gao Y, Kuwabara H, Dannals RF. Development of radioligands with optimized imaging properties for quantification of nicotinic acetylcholine receptors by positron emission tomography. Life Sci. 2010;86:575-84.

70. Bohnen NI, Kaufer DI, Hendrickson R, Ivanco LS, Lopresti BJ, Koeppe RA, et al. Degree of inhibition of cortical acetylcholinesterase activity and cognitive effects by donepezil treatment in Alzheimer's disease. J Neurol Neurosurg Psychiatry. 2005;76: 315-9.

71. Kuhl DE, Minoshima S, Frey KA, Foster NL, Kilbourn MR, Koeppe RA. Limited donepezil inhibition of acetylcholinesterase measured with positron emission tomography in living Alzheimer cerebral cortex. Ann Neurol. 2000;48:391-5.

72. Shinotoh H, Aotsuka A, Fukushi K, Nagatsuka S, Tanaka N, Ota $\mathrm{T}$, et al. Effect of donepezil on brain acetylcholinesterase activity in patients with AD measured by PET. Neurology. 2001;56:40810.

73. Kaasinen V, Någren K, Järvenpää T, Roivainen A, Yu M, Oikonen $\mathrm{V}$, et al. Regional effects of donepezil and rivastigmine on cortical acetylcholinesterase activity in Alzheimer's disease. J Clin Psychopharmacol. 2002;22:615-20.

74. Kadir A, Darreh-Shori T, Almkvist O, Wall A, Grut M, Strandberg $\mathrm{B}$, et al. PET imaging of the in vivo brain acetylcholinesterase activity and nicotine binding in galantamine-treated patients with AD. Neurobiol Aging. 2008;29:1204-17.

75. Maelicke A, Samochocki M, Jostock R, Fehrenbacher A, Ludwig $\mathrm{J}$, Albuquerque EX, et al. Allosteric sensitization of nicotinic receptors by galantamine, a new treatment strategy for Alzheimer's disease. Biol Psychiatry. 2001;49:279-88.

76. Marsden CD. Basal ganglia disease. Lancet. 1982;320:1141-7.

77. Jellinger KA. Pathology of Parkinson's disease. Mol Chem Neuropathol. 1991;14:153-97.

78. Samii A, Nutt JG, Ransom BR. Parkinson's disease. Lancet. 2004;363:1783-93.

79. Whitehouse PJ, Hedreen JC, White CL, Price DL. Basal forebrain neurons in the dementia of Parkinson disease. Ann Neurol. 1983;13:243-8.

80. Schrag A. Psychiatric aspects of Parkinson's disease. J Neurol. 2004;251:795-804.

81. Aarsland D, Andersen K, Larsen JP, Lolk A. Prevalence and characteristics of dementia in Parkinson disease: an 8-years prospective study. Arch Neurol. 2003;60:387-92.

82. Hely MA, Reid WGJ, Adena MA, Halliday GM, Morris JGL. The Sydney multicenter study of Parkinson's disease: the inevitability of dementia at 20 years. Mov Disord. 2008;23:837-44.

83. Aarsland D, Bronnick K, Williams-Gray C, Weintraub D, Marder $\mathrm{K}$, Kulisevsky J, et al. Mild cognitive impairment in Parkinson disease: a multicenter pooled analysis. Neurology. 2010;75:10629.

84. Muslimovic D, Post B, Speelman JD, Schmand B. Cognitive profile of patients with newly diagnosed Parkinson disease. Neurology. 2005;65:1239-45.

85. McKeith IG, Galasko D, Kosaka K, Perry EK, Dickson DW, Hansen LA, et al. Consensus guidelines for the clinical and pathologic diagnosis of dementia with Lewy bodies (DLB): report of the consortium on DLB international workshop. Neurology. 1996;47:1113-24.

86. Whitehouse PJ, Martino AM, Wagster MV, Price DL, Mayeux R, Atack JR, et al. Reductions in [3H]nicotinic acetylcholine binding in Alzheimer's disease and Parkinson's disease: an autoradiographic study. Neurology. 1988;38:720-3.

87. Whitehouse PJ, Hedreen JC, White CL, Price DL. Basal forebrain neurons in the dementia of Parkinson disease. Ann Neurol. 1983;13:243-8.

88. Court JA, Piggott MA, Lloyd S, Cookson N, Ballard CG, McKeith IG, et al. Nicotine binding in human striatum: elevation in schizophrenia and reductions in dementia with Lewy bodies, Parkinson's disease and Alzheimer's disease and in relation to neuroleptic medication. Neuroscience. 2000;98:79-87.

89. Graham AJ, Martin-Ruiz CM, Teaktong T, Ray MA. Human brain nicotinic receptors, their distribution and participation in neuropsychiatric disorders. Curr Drug Targets CNS Neurol Disord. 2002;1:387-97.

90. Ruberg M, Rieger F, Villageois A, Bonnet AM, Agid Y. Acetylcholinesterase and butyrylcholinesterase in frontal cortex and cerebrospinal fluid of demented and non-demented patients with Parkinson's disease. Brain Res. 1986;362:83-91.

91. Rinne JO, Myllykyla T, Lo P. A postmortem study of brain nicotinic receptors in Parkinson's and Alzheimer's disease. Brain Res. 1991;547:155-8.

92. Perry EK, Morris CM, Court JA, Cheng A, Fairbairn AF, McKeith IG, et al. Alteration in nicotine binding sites in Parkinson's disease, Lewy body dementia and Alzheimer's disease: possible index of early neuropathology. Neuroscience. 1995;64:385-95. 
93. Mendez MF, Shapira JS, McMurtray A, Licht E. Preliminary findings: behavioral worsening on donepezil in patients with frontotemporal dementia. Am J Geriatr Psychiatr. 2007;15:84-7.

94. Perry EK, Irving D, Kerwin JM, McKeith IG, Thompson P, Collerton D, et al. Cholinergic transmitter and neurotrophic activities in Lewy body dementia: similarity to Parkinson's and distinction from Alzheimer disease. Alzheimer Dis Assoc Disord. 1993;7:69-79.

95. Shiozaki K, Iseki E, Uchiyama H, Watanabe Y, Haga T, Kameyama K, et al. Alterations of muscarinic acetylcholine receptor subtypes in diffuse Lewy body disease: relation to Alzheimer's disease. J Neurol Neurosurg Psychiatry. 1999;67: 209-13.

96. Mulholland GK, Kilbourn MR, Sherman P, Carey JE, Frey KA, Koeppe RA, et al. Synthesis, in vivo biodistribution and dosimetry of [11C]N-methylpiperidyl benzilate ([11C]NMPB), a muscarinic acetylcholine receptor antagonist. Nucl Med Biol. 1995;22:13-7.

97. Otto CA, Mulholland GK, Perry SE, Combs R, Sherman PS, Fisher SJ. In vitro and ex vivo evaluation of cyclic aminoalkyl benzilates as potential emission tomography ligands for the muscarinic receptor. Nucl Med Biol. 1989;16:51-5.

98. Koeppe RA, Frey KA, Zubieta JA, Fessler JA, Mulholland GK, Kilbourn MR, et al. Tracer kinetic analysis of [C-11]N-methyl-4piperidyl benzilate binding to muscarinic cholinergic receptors. J Nucl Med. 1992;33:882.

99. Kloog Y, Egozi Y, Sokolovsky M. Characterization of muscarinic acetylcholine receptors from mouse brain: evidence for regional heterogeneity and isomerization. Mol Pharmacol. 1979;15:54558.

100. Lorenz R, Samnick S, Dillmann U, Schiller M, Ong MF, Faßbender K, et al. Nicotinic $\alpha 4 \beta 2$ acetylcholine receptors and cognitive function in Parkinson's disease. Acta Neurol Scand. 2014;130:164-71.

101. Dani JA, Bertrand D. Nicotinic acetylcholine receptors and nicotinic cholinergic mechanisms of the central nervous system. Annu Rev Pharmacol Toxicol. 2007;47:699-729.

102. Pimlott SL, Piggott M, Owens J, Greally E, Court JA, Jaros E, et al. Nicotinic acetylcholine receptor distribution in Alzheimer's disease, dementia with Lewy bodies, Parkinson's disease, and vascular dementia: in vitro binding study using 5-[(125)I]-a85380. Neuropsychopharmacology. 2004;29:108-16.

103. Buckingham SD, Jones AK, Brown LA, Sattelle DB. Nicotinic acetylcholine receptor signaling: roles in Alzheimer's disease and amyloid neuroprotection. Pharmacol Rev. 2009;61:39-61.

104. Hu M, Waring JF, Gopalakrishnan M, Li J. Role of GSK-3beta activation and alpha7 nAChRs in Abeta(1-42)-induced tau phosphorylation in PC12 cells. J Neurochem. 2008;106:1371-7.

105. Dziewczapolski G, Glogowski CM, Masliah E, Heinemann SF. Deletion of the $\alpha 7$ nicotinic acetylcholine receptor gene improves cognitive deficits and synaptic pathology in a mouse model of Alzheimer's disease. J Neurosci. 2009;29: 8805-15.

106. Horti AG, Gao Y, Kuwabara H, Wang Y, Abazyan S, Yasuda RP, et al. 18F-ASEM, a radiolabeled antagonist for imaging the $\alpha 7$ nicotinic acetylcholine receptor with PET. J Nucl Med. 2014;55: 672-7.

107. Wong DF, Kuwabara H, Pomper M, Holt DP, Brasic JR, George N, et al. Human brain imaging of $\alpha 7 \mathrm{nAChR}$ with [(18)F]ASEM: a new PET radiotracer for neuropsychiatry and determination of drug occupancy. Mol Imaging Biol. 2014; $16: 730-8$. 